\title{
Ambient Fine and Ultrafine Particle Measurements and Their Correlations with Particulate PAHs at an Elementary School Near a Highway
}

\author{
Sanghwan Song*, Domyung Paek ${ }^{1)}$, Young-Mee Lee, Chulwoo Lee, Chunghee Park and Seung-Do Yu \\ Environmental Health Research Division, National Institute of Environmental Research, Incheon, Korea \\ ${ }^{1)}$ Graduate School of Public Health, Seoul National University, Seoul, Korea
}

*Corresponding author. Tel: +82-32-560-7121, E-mail: sanghwan@korea.kr

\begin{abstract}
Ambient particulate matter (PM) and particle-bound polycyclic aromatic hydrocarbon (PAH) concentrations were measured continuously for 70 days at a Korean elementary school located near a highway. The $\mathrm{PM}_{10}$, $\mathrm{PM}_{2.5}$, and $\mathrm{PM}_{1}$ values were measured with a lightscattering, multi-channel, aerosol spectrometer (Grimm, Model 1.107). The number concentrations of the particles were measured using a scanning mobility particle sizer and counter (SMPS $+\mathrm{C}$ ) which counted particles from 11.1 to $1083.3 \mathrm{~nm}$ classified in 44 channels. Particle-bound PAHs were measured with a direct reading, photoelectric aerosol sensor. The daily $\mathrm{NO}_{2}, \mathrm{SO}_{2}$, and $\mathrm{CO}$ concentrations were obtained from a national air-monitoring station located near the school. The average concentrations of $\mathrm{PM}_{10}$, $\mathrm{PM}_{2.5}$, and $\mathrm{PM}_{1}$ were $75.3,59.3$, and $52.1 \mu \mathrm{g} / \mathrm{m}^{3}$, respectively. The average number concentration of the ultrafine particles (UFPs) was $46,307 / \mathrm{cm}^{3}$, and the averaged particle-bound PAHs concentration was 17.9 $\mathrm{ng} / \mathrm{m}^{3}$ during the study period. The ambient UFP variation was strongly associated with traffic intensity, particularly peak concentrations during the traffic rush hours. Particles $<100 \mathrm{~nm}$ corresponded to trafficrelated pollutants, including PAHs. Additional longterm monitoring of ambient UFPs and high-resolution traffic measurements should be carried out in future studies. In addition, transient variations in the ambient particle concentration should be taken into consideration in epidemiology studies in order to examine the short-term health effects of urban UFPs.
\end{abstract}

Key words: Ultrafine particles, Polycyclic aromatic hydrocarbons, Particulate matter, Traffic-related pollutants, Highway

\section{INTRODUCTION}

Epidemiological studies have demonstrated that airborne particulate matter (PM) is associated with adverse health outcomes, including increased respiratory and cardiovascular illnesses and hospitalization rates (Pope and Dockery, 2006; Brunekreef and Forsberg, 2005; Pope et al., 2002; Dockery, 2001). However, it is unclear which PM properties are responsible for the health effects. Ambient PM is composed of heterogeneous compounds varying in size, number, chemical composition, surface area, concentration, and source (Brook et al., 2004). It has been suggested that ambient PM size is an important factor in toxicity, with biological activity increasing as the particle size decreases (Oberdorster, 1996).

Ambient particles are measured as PM mass and classified according to aerodynamic diameter into the following size fractions: particles $<10 \mu \mathrm{m}\left(\mathrm{PM}_{10}\right)$, coarse thoracic particles of 2.5 to $10 \mu \mathrm{m}\left(\mathrm{PM}_{2.5-10}\right)$, and fine particles $<2.5 \mu \mathrm{m}\left(\mathrm{PM}_{2.5}\right)$ or $<1 \mu \mathrm{m}\left(\mathrm{PM}_{1}\right)$. Ultrafine particles (UFPs) are receiving increasing interest in the scientific community due to their small size, $<0.1 \mu \mathrm{m}$ and potential health effects. Trafficrelated emissions are the primary source of ambient urban fine and ultrafine particles (Fine et al., 2004; Zhang et al., 2004). Particles emitted from vehicles are $<0.1 \mu \mathrm{m}$ in size and are the major contributor to urban particulate pollution (Kittelson, 1998). In addition, they can increase allergic sensitization (Diaz-Sanchez et al., 2000; Diaz-Sanchez et al., 1999). Several studies have shown that a large proportion of urban UFPs consist of primary combustion products from traffic emissions such as diesel exhaust particles which include organic compounds, elemental carbon, soot, and metals (Kim et al., 2002; Bockhorn, 2000; Cass et al., 2000).

UFPs correspond to nucleation and Aitken modes and are typically fresh combustion emissions, of which 
vehicle engines are the primary source in urban areas (Sioutas et al., 2005). Particles emitted from vehicles are the result of gas phase species nucleation, forming condensed phase species in newly formed particles that have had little chance to grow (i.e., nucleation mode) or in recently formed particles that are actively undergoing coagulation (i.e., Aitken mode) (Araujo and Nel, 2009). UFPs are likely more toxic than larger particles (Li et al., 2003; Donaldson et al., 2002) because of their size. The larger numbers and surface area per unit mass of UFPs are important toxicologically due to the enhanced tissue penetration and oxidative stress that induces cellular damage (Oberdorster et al., 2005; Li et al., 2003). In addition, urban UFPs have high concentrations of toxic substances, including soluble metals, polycyclic aromatic hydrocarbons (PAHs), and quinines, all of which contribute to inflammation and oxidative stress (Li et al., 2008; Nel et al., 2006).

High ambient PAH concentrations are associated with increased urban vehicle traffic volumes because most PAHs are generated from incomplete combustion (Sapkota and Buckley, 2003; Levy et al., 2001). Ambient PAHs are partitioned between the particulate and gas phase, primarily as fine and sub-micrometer particles $<1-3 \mu \mathrm{m}$ in size (Kaupp and McLachlan, 2000), and, therefore, they can penetrate deep into the bronchial system.

Epidemiologic panel studies have evaluated the short-term effects of temporal environmental concentrations on health outcomes. Ambient particles may peak during rush hour when rapid changes occur in the concentration of vehicle exhaust particles in ambient urban air (Zhu et al., 2002). Continuous, realtime PM monitoring is necessary in order to characterize transient variations in atmospheric PM and to understand the effects of these variations on human health. Studies based on continuous measurements of particle size distribution have indicated that UFP concentrations are positively correlated with traffic volume (Buonocore et al., 2009; Fruin et al., 2008), nitrogen oxide (Kwasny et al., 2010; Noble et al., 2003), and black carbon (Gonzalez et al., 2011), with different size distributions and temporal trends (Kim et al., 2002; Zhu et al., 2002) in different urban areas. However, few studies have evaluated airborne UFP concentrations in Korean urban centers (Park et al., 2008).

This study presents the results of continuous particle and gaseous air pollutant measurements in an urban area in order to determine the temporal variation in ambient fine PM, UFP, and particle-bound PAH (p$\mathrm{PAH}$ ) concentrations at an urban elementary school in Korea. We examined the diurnal variation in particle concentrations in relation to traffic patterns and assessed their correlations with other pollutants, especially p-PAHs that originate from vehicle emissions. The results of this study provide information on the potential exposure of schoolchildren to particulate pollutants.

\section{MATERIALS AND METHODS}

\section{1 Monitoring Site}

Monitoring was conducted on the roof of a four-story elementary school $\left(37^{\circ} 28^{\prime} 05^{\prime \prime} \mathrm{N}, 126^{\circ} 40^{\prime} 41^{\prime \prime} \mathrm{E}\right)$ in Nam$\mathrm{gu}$, a mixed commercial and residential area of the city of Incheon, South Korea. The school was located near a main road and approximately $200 \mathrm{~m}$ from a sixlane highway with an average traffic volume of 98,000 vehicles/day. The site was also located within $5 \mathrm{~km}$ of the Incheon industrial complex. Therefore, traffic and plant operations were considered the main ambient air pollution sources.

\section{2 Measurements}

The real-time concentration of particles was measured continuously for 67 days from March 31 to June 6, 2009 at the fixed monitoring site. Particulate matter mass was measured with a multi-channel (31 sizes, 0.25-32 $\mu \mathrm{m}$ ) aerosol spectrometer (Model 1.107, Grimm Aerosol Technik, Germany), which sampled the particles at a rate of $1.2 \mathrm{~L} / \mathrm{min}$ using a laser light scattering optical particle counter. The particle counts from each of the channels were converted to size categories of $\mathrm{PM}_{10}, \mathrm{PM}_{2.5}$, and $\mathrm{PM}_{1}$ every $5 \mathrm{~min}$. The daily gravimetric PM measurements were collected in parallel (45 to 50 days) by low-volume $(16.7 \mathrm{~L} / \mathrm{min}$ for 23 hr) particulate samplers (FH95, Thermo, Germany) for comparison to the continuous light-scattering measurements. The PM mass was collected using Teflon filters ( $47 \mathrm{~mm}$ PTEF, Zefluor, $2 \mu \mathrm{m}$ pore size) with a flow rate of $16.7 \mathrm{~L} / \mathrm{min}$ for $23 \mathrm{hr}(09: 00-08: 00)$ and weighed using a micro-balance (Satorious, $0.01 \mathrm{mg}$ reading precision). We found that the measurement from the aerosol spectrometer was in excellent agreement with the PM filter-based measurements $\left(\mathrm{r}^{2}>\right.$ $0.98)$.

The number concentrations of the particles were measured using a scanning mobility particle sizer and counter (SMPS +C) composed of a differential mobility analyzer (DMA; Grimm model 5.5-900) and a condensation particle counter (CPC; Grimm Model 5.400), which counted particles between 11.1 to $1083.3 \mathrm{~nm}$ in size and classified them into 44 channels by scanning every $7 \mathrm{~min}$. The instruments can count up to $10^{7}$ particles $/ \mathrm{cm}^{3}$ with $10 \%$ accuracy when operated at a 0.3 
$\mathrm{L} / \mathrm{min}$ aerosol and a $3 \mathrm{~L} / \mathrm{min}$ sheath flow rate. Data were collected with software provided by the manufacturer, which also allows for correction of losses in the system. The UFP number concentration was the sum of 25 channels from between 11.1 and $101 \mathrm{~nm}$ in size $\left(\mathrm{NC}_{0.01-0.1}\right)$. These sizes represented the characteristics of the particles most likely to be produced by vehicle traffic. The accumulation mode particle number $\mathrm{NC}_{0.1-1}$ was calculated by adding the 18 channels between 111 and $930 \mathrm{~nm}$ in size, representing a large portion of the sub-micrometer particle mass. Particle number concentrations from a series of six days with $<100$ measurements and/or those collected for less than 12 hours each day were excluded. Particle-bound PAHs were measured with a photoelectric aerosol sensor direct reading instrument (PAS 2000, EcoChem Technologies) which detected particulate PAHs by measuring the electrons emitted by organic molecules on particles irradiated by ultraviolet light. The instrument is useful for measuring four or more ring PAHs adsorbed to a particle having an aerodynamic size greater than $1 \mu \mathrm{m}$ with a nominal detection limit of $3 \mathrm{ng} / \mathrm{m}^{3}$ (Cowen et al., 2001; Burtscher, 1992). However, previous studies have shown that gas-phase PAHs with two to four rings are not detected by the PAS (Ramamurthi and Chuang, 1997).

Daily $\mathrm{NO}_{2}, \mathrm{SO}_{2}$, and $\mathrm{CO}$ concentrations were obtained from a national air-monitoring station located $2 \mathrm{~km}$ east of the school. We used 1-hr averages for the continuous measurements. Diurnal variation was assessed for both weekdays and weekends in order to examine the effects of traffic on the particulate concentrations. The Pearson correlation coefficients were used to analyze the relationship between the ambient PM and pPAHs and the gaseous pollutants.

\section{RESULTS AND DISCUSSION}

\subsection{Mass and Number Concentrations of Particles}

The air pollutants data are summarized in Table 1. During the study period, the 1-hour average concentrations (mean $\pm \mathrm{SD}$ ) of $\mathrm{PM}_{10}, \mathrm{PM}_{2.5}$, and $\mathrm{PM}_{1}$ were 75.3 $\pm 43.5,59.3 \pm 34.4$, and $52.1 \pm 31.6 \mu \mathrm{g} / \mathrm{m}^{3}$, respectively. Their variations were relatively high because the hourly peak and lowest values were included. Daily $\mathrm{PM}_{10}$ levels greater than $100 \mu \mathrm{g} / \mathrm{m}^{3}$ were observed for ten of the 70 days of the study period. $\mathrm{PM}_{2.5}$ and $\mathrm{PM}_{1}$ accounted for $79 \%$ and $68 \%$ of the $\mathrm{PM}_{10}$ mass concentration, respectively. The 1-hour average $\mathrm{NC}_{0.01-0.1}$, and $\mathrm{NC}_{0.01-0.05}$ were 46,307 $\pm 34,644$ and 37,915 \pm $30,303 \mathrm{~cm}^{3}$, respectively. The average P-PAHs concentration was $17.9 \pm 13.8 \mathrm{ng} / \mathrm{m}^{3}$ during the study period. The highest particle number was observed in the UFP fraction range of 0.01 to $0.1 \mu \mathrm{m}$ (Fig. 1). The UFPs accounted for $83 \%$ of the total particle number concentration.

The results of our study showed relatively high air pollutant levels. The particle number concentrations and $\mathrm{PM}_{10}$ and $\mathrm{PM}_{2.5}$ values were somewhat higher than levels reported in other areas of Korea (Park et al., 2008) and much higher than the levels reported in European cities (Timonen et al., 2004; Pekkanen et al., 2002). High ambient particle concentrations might have been emitted from the highway near the monitoring site. The p-PAH concentration was not much greater than the PAS measurements in other urban centers, e.g., $29 \mathrm{ng} / \mathrm{m}^{3}$ in Tokyo, Japan; $52 \mathrm{ng} / \mathrm{m}^{3}$ in Bangkok, Thailand (Chetwittayachan et al., 2002); and 19 to $92 \mathrm{ng} / \mathrm{m}^{3}$ in Basel, Switzerland (Junker et al., 2000). Although PAS measurements are limited to the PAH concentration in particles, Chetwittayachan et al. found that PAS

Table 1. Means of the 1-hour average concentrations of air pollutants.

\begin{tabular}{|c|c|c|c|c|c|c|c|c|}
\hline & \multirow{2}{*}{$\begin{array}{l}\text { No. of } \\
\text { hour }\end{array}$} & \multirow{2}{*}{ Mean } & \multirow{2}{*}{$\mathrm{SD}^{\mathrm{a}}$} & \multicolumn{3}{|c|}{ Percentile } & \multirow{2}{*}{ Minimum } & \multirow{2}{*}{ Maximum } \\
\hline & & & & 25 th & 50 th & 75 th & & \\
\hline $\mathrm{PM}^{\mathrm{b}}{ }_{10}\left(\mu \mathrm{g} / \mathrm{m}^{3}\right)$ & 1597 & 75.3 & 43.5 & 44.2 & 63.9 & 95.2 & 5.4 & 271.0 \\
\hline $\mathrm{PM}_{2.5}\left(\mu \mathrm{g} / \mathrm{m}^{3}\right)$ & 1597 & 59.3 & 34.4 & 34.5 & 50.5 & 77.2 & 4.4 & 212.4 \\
\hline $\mathrm{PM}_{1}\left(\mu \mathrm{g} / \mathrm{m}^{3}\right)$ & 1597 & 52.1 & 31.6 & 29.6 & 43.8 & 69.1 & 3.4 & 191.1 \\
\hline $\mathrm{NC}_{0.1-0.5}{ }^{\mathrm{c}}\left(1,000 / \mathrm{cm}^{3}\right)$ & 1465 & 7.349 & 4.569 & 3.662 & 6.076 & 10.218 & 0.481 & 25.752 \\
\hline $\mathrm{NC}_{0.01-0.1}\left(1,000 / \mathrm{cm}^{3}\right)$ & 1465 & 46.307 & 34.644 & 21.667 & 35.979 & 61.889 & 2.222 & 263.426 \\
\hline $\mathrm{NC}_{0.01-0.05}\left(1,000 / \mathrm{cm}^{3}\right)$ & 1465 & 37.915 & 30.303 & 16.584 & 28.982 & 50.158 & 1.377 & 244.224 \\
\hline P-PAHs ${ }^{\mathrm{d}}\left(\mathrm{ng} / \mathrm{m}^{3}\right)$ & 1597 & 17.9 & 13.8 & 8.4 & 14.4 & 23.1 & $<3$ & 99.5 \\
\hline $\mathrm{NO}_{2}(\mathrm{ppm})$ & 1478 & 0.033 & 0.018 & 0.02 & 0.029 & 0.041 & 0.001 & 0.113 \\
\hline $\mathrm{SO}_{2}(\mathrm{ppm})$ & 1478 & 0.01 & 0.006 & 0.006 & 0.009 & 0.012 & 0.001 & 0.059 \\
\hline $\mathrm{CO}(\mathrm{ppm})$ & 1478 & 0.7 & 0.3 & 0.5 & 0.6 & 0.8 & 0.1 & 2.6 \\
\hline
\end{tabular}

asD, standard deviation

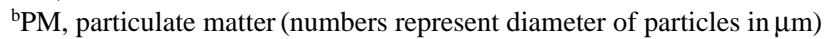

${ }^{\mathrm{c}} \mathrm{NC}$, number concentration of particles (numbers represent diameter of particles in $\mu \mathrm{m}$ )

${ }^{\mathrm{d}} \mathrm{P}-\mathrm{PAHs}$, particle-bound PAHs concentration 


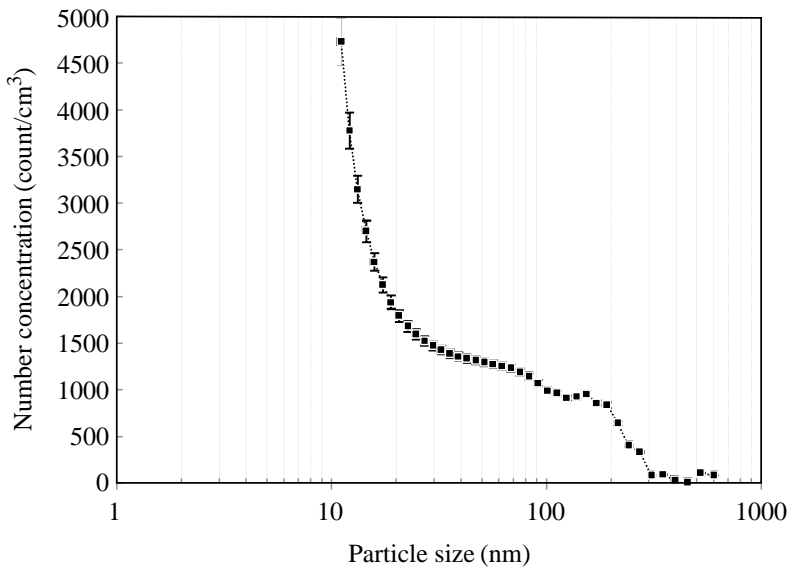

Fig. 1. Average number concentrations ( \pm standard error) of particles from $10.1-1,000 \mathrm{~nm}$ in size measured over 64 days.

level exhibited a strong correlation $\left(\mathrm{r}^{2}=0.79\right)$ with the total concentration of 11 carcinogenic PAHs as determined by gas chromatography/mass spectrometry (Chetwittayachan et al., 2002).

\section{2 Diurnal Trends}

Fig. 2 shows the diurnal variations in the gaseous and particulate pollutants. The plot shows the typical traffic-related time-series patterns for the particle measurements. Two peaks, associated with the morning and evening rush hours, were observed in the UFP and pPAH measurements. The UFP number concentration peaked between 06:00 and 09:00 and then again between 18:00 and 22:00. The diurnal pattern of the pPAHs was similar to that of the UFP. The concentration of the PAHs remained elevated throughout the morning rush hour, decreased in the afternoon, and increased in the evening. The evening UFP and PAH concentrations continued to rise until the late evening. This might be due to the late evening rush hour (22:00) that commonly occurred on the highway near the monitoring site (KEC, 2004). From 22:00 until midnight, the concentrations of UFP and p-PAHs started to decrease due to decreased traffic activity. The PM mass fractions of $\mathrm{PM}_{10}, \mathrm{PM}_{2.5}$, and $\mathrm{PM}_{1}$ had the highest concentrations during the morning rush hour but did not increase as much as the UFPs in the evening.

The pollutants, especially the UFPs and PAHs, decreased on the weekends. The PM mass fraction diurnal trends did not differ between the weekdays and weekends, whereas the UFPs and p-PAHs had different patterns on the weekdays than on the weekends. On the weekends, the variations in the UFP and p-PAH did not show evening rush hour peaks. Fig. 3 shows the diurnal trends of the ambient particles and p-PAHs
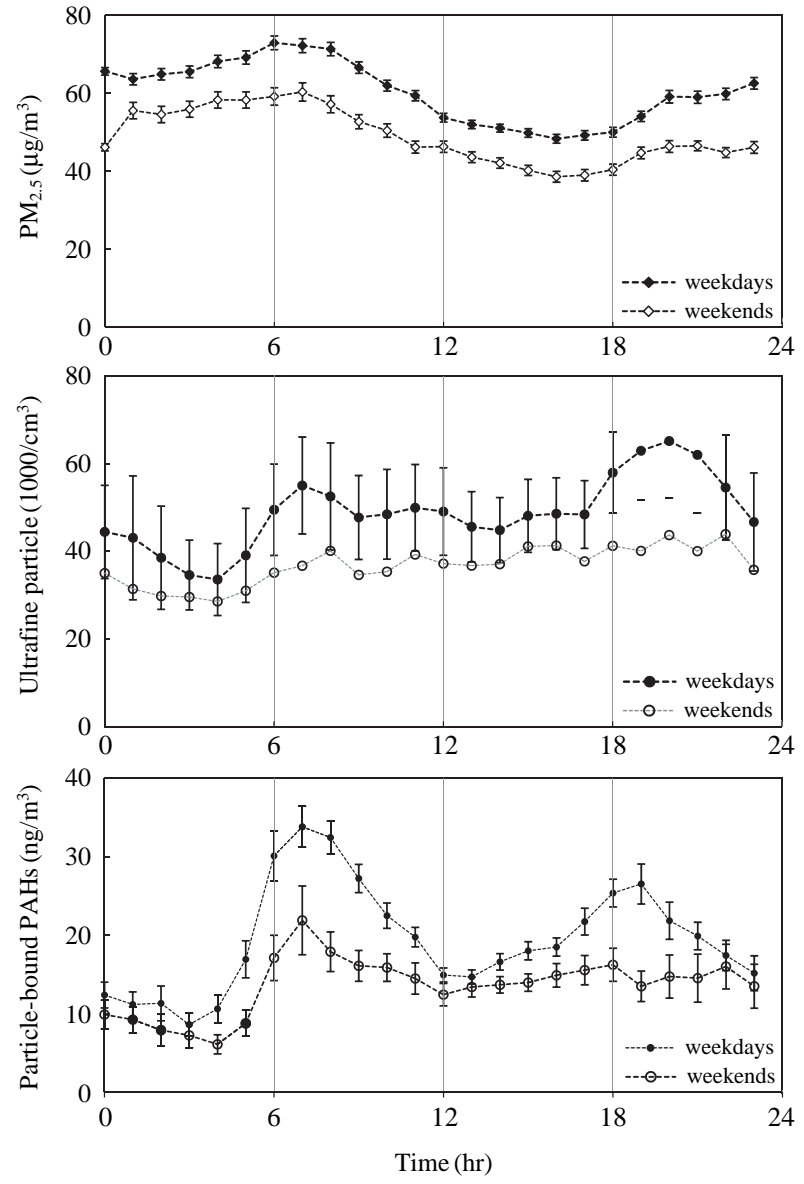

Fig. 2. Hourly mean concentrations ( \pm standard error) of ambient particles and p-PAHs on weekdays and weekends.

concentration on the highest and lowest PAH pollutions day. On the highest PAHs pollution day (Friday), the diurnal pattern of the p-PAHs was similar to that of the UFP and $\mathrm{PM}_{1}$, showing the typical two peaks during the morning and evening rush hours. However, these similar patterns were not observed on the lowest PAHs pollution day (Sunday).

Normally, traffic emissions are the primary source of urban ambient fine PM pollution (Fine et al., 2004). The fresh particles emitted from vehicles have short life spans as they coalesce with larger particles. In addition, the number size distribution was altered by the aerosol dynamical processes, including dilution with clean air, polluted air entrainment, vapor condensation, and particle coagulation (Wehner et al., 2002). The results of previous epidemiological studies have indicated that short term $(1 \mathrm{hr})$ exposure to DEPs could produce a pulmonary inflammation response in healthy subjects (Salvi et al., 2000; Salvi et al., 1999). Therefore, 24-hr average data might underestimate the exposure-related adverse health effects. However, more 
Table 2. Pearson correlation coefficients among the ambient pollutant concentrations.

\begin{tabular}{|c|c|c|c|c|c|c|c|c|c|c|c|}
\hline & $\mathrm{PM}_{10}$ & $\mathrm{PM}_{2.5}$ & $\mathrm{PM}_{1}$ & $\mathrm{NC}_{0.1-0.5}$ & $\mathrm{NC}_{0.01-0.1}$ & $\mathrm{NC}_{0.01-0.05}$ & P-PAHs & $\mathrm{NO}_{2}$ & $\mathrm{O}_{3}$ & $\mathrm{SO}_{2}$ & $\mathrm{CO}$ \\
\hline $\mathrm{PM}_{10}$ & 1 & & & & & & & & & & \\
\hline $\mathrm{PM}_{2.5}$ & 0.97 & 1 & & & & & & & & & \\
\hline $\mathrm{PM}_{1}$ & 0.96 & 1 & 1 & & & & & & & & \\
\hline $\mathrm{NC}_{0.1-0.5}$ & 0.77 & 0.78 & 0.77 & 1 & & & & & & & \\
\hline $\mathrm{NC}_{0.01-0.1}$ & 0.47 & 0.45 & 0.45 & 0.86 & 1 & & & & & & \\
\hline $\mathrm{NC}_{0.01-0.05}$ & 0.43 & 0.42 & 0.41 & 0.83 & 1 & 1 & & & & & \\
\hline P-PAHs & 0.38 & 0.4 & 0.4 & 0.55 & 0.47 & 0.44 & 1 & & & & \\
\hline $\mathrm{NO}_{2}$ & 0.78 & 0.77 & 0.76 & 0.69 & 0.45 & 0.41 & 0.6 & 1 & & & \\
\hline $\mathrm{SO}_{2}$ & 0.86 & 0.82 & 0.81 & 0.78 & 0.63 & 0.59 & 0.46 & 0.77 & 0.08 & 1 & \\
\hline $\mathrm{CO}$ & 0.83 & 0.81 & 0.8 & 0.7 & 0.44 & 0.39 & 0.56 & 0.85 & -0.17 & 0.82 & 1 \\
\hline
\end{tabular}
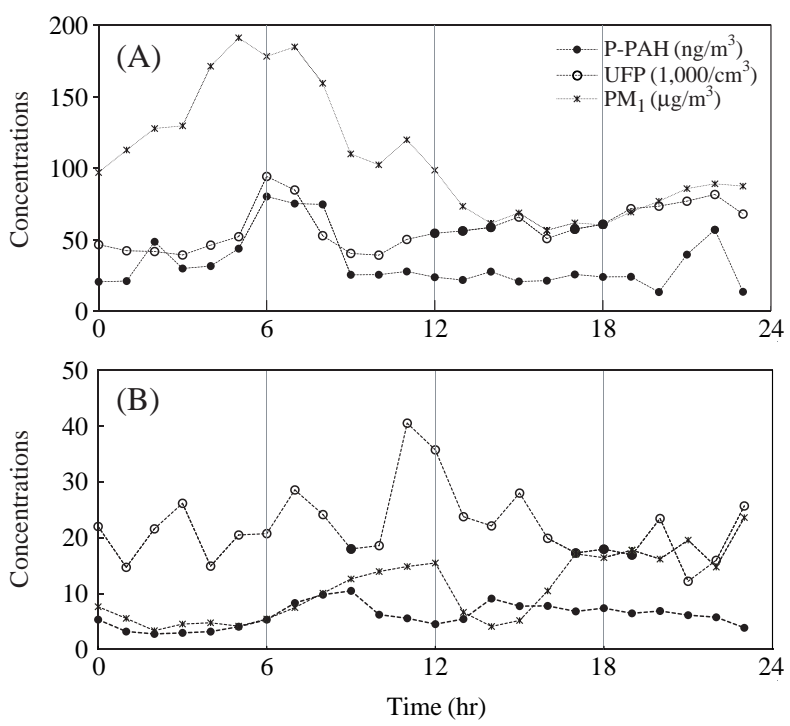

Fig. 3. Hourly mean concentrations of ambient particles and p-PAHs on a highest (A) and lowest (B) PAH pollution day.

research is needed to explore the relationships between various sizes of UFPs and traffic volume or other traffic-related pollutant proxies.

\section{3 Pollutants Concentration Correlations}

Ambient particles and gaseous pollutant concentrations were intercorrelated. The Pearson correlation analysis showed a high correlation $(r>0.95)$ among $\mathrm{PM}_{10}, \mathrm{PM}_{2.5}$, and $\mathrm{PM}_{1}$. In addition, $\mathrm{PM}_{2.5}$ was significantly $(p<0.001)$ correlated with $\mathrm{NO}_{2}(\mathrm{r}=0.77), \mathrm{SO}_{2}$ $(\mathrm{r}=0.82)$, and $\mathrm{CO}(\mathrm{r}=0.81)$. The UFPs were moderately $(p<0.05)$ correlated with $\mathrm{PM}_{10}(\mathrm{r}=0.47), \mathrm{PM}_{2.5}(\mathrm{r}=$ $0.45), \mathrm{NO}_{2}(\mathrm{r}=0.46), \mathrm{SO}_{2}(\mathrm{r}=0.63)$, and $\mathrm{CO}(\mathrm{r}=0.44)$.

Fig. 4 illustrates the correlation coefficients of the hourly mean concentrations of 38 particle size classes from 10 to $454 \mathrm{~nm}$ and p-PAHs. The correlation coefficients for UFPs with p-PAHs and $\mathrm{NO}_{2}$ were higher than the correlation of the UFPs with $\mathrm{PM}_{2.5}$ and CO. The particle number correlation coefficients with $\mathrm{PM}_{2.5}$

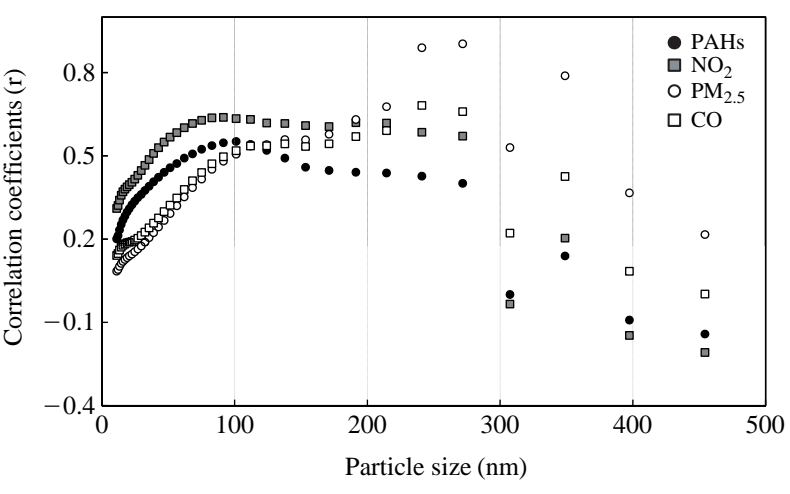

Fig. 4. Pearson correlation coefficients among the 1-hr mean concentrations of $\mathrm{PM}_{2.5}$, p-PAHs, $\mathrm{NO}_{2}, \mathrm{CO}$ and particle number in 38 size classes $(10-454 \mathrm{~nm})$.

and $\mathrm{CO}$ increased in relation to particle sizes up to 300 $\mathrm{nm}$. The correlation coefficients between particle number concentration and the p-PAHs and $\mathrm{NO}_{2}$ remained elevated in relation to particle size up to $100 \mathrm{~nm}$ and decreased for larger particle sizes. This result suggests that the particle number concentration of $100 \mathrm{~nm}$ particles originated predominantly from traffic emission particles, DEPs in particular.

With respect to human health, UFPs from diesel exhaust have mucosal adjuvant properties and can exacerbate allergic inflammation, even turning a harmless neoantigen into an allergen that induces allergen-specific IgE (Diaz-Sanchez et al., 2000; Diaz-Sanchez et al., 1999; Nel et al., 1998). Studies using a rat model suggest that ambient UFPs act as adjuvant substances for allergic sensitization, probably due to their high oxidant potential (Li et al., 2009; de Haar et al., 2006).

\section{CONCLUSIONS}

The results of our study showed relatively high air pollutant levels at an elementary school located near a highway. In the daily change profiles of the measured 
particulate pollutants, UFPs and p-PAHs showed clearer, higher peak concentrations in the morning and evening compared to the PM mass fraction, indicating that they were strongly related to the high traffic rates during the morning and evening rush hours. Throughout the day, the ambient particle variation showed marked peaks that could lead to high acute exposure, especially during the morning and evening rush hours. These fresh particles emitted from vehicles have short life spans as they coalesce with larger particles. Therefore, 24-hr average data might underestimate the exposurerelated adverse health effects.

In the correlation analysis, the correlations of sizeresolved particles with particle-bound PAHs and other gaseous pollutants depended on particle size. The correlation coefficients between size-resolved particle concentrations and traffic-related pollutants, such as p-PAHs and $\mathrm{NO}_{2}$, increased up to 100 -nm particle sizes and declined with larger particles. This result suggests that the particle number concentration of $100 \mathrm{~nm}$ particles originated predominantly from traffic emission particles, DEPs in particular.

In conclusion, ambient UFP variation is strongly associated with traffic intensity, particularly peak concentrations occurring during the traffic rush hours. Particles $<100 \mathrm{~nm}$ corresponded to traffic-related pollutants, including PAHs. Additional long-term monitoring of ambient UFPs and high-resolution traffic measurements should be explored in future studies. In addition, transient variations in the ambient particles concentrations should be taken into consideration in future epidemiology studies in order to examine the short-term health effects of urban UFPs.

\section{REFERENCES}

Araujo, J.A., Nel, A.E. (2009) Particulate Matter and Atherosclerosis: Role of Particle Size, Composition and Oxidative Stress. Particle and Fibre Toxicology 6, 24.

Bockhorn, H. (2000) Ultrafine Particles from Combustion Sources: Approaches to What We Want to Know. Philosophical Transactions of the Royal Society of London. Series A: Mathematical, Physical and Engineering Sciences 358, 2659-2672.

Brook, R.D., Franklin, B., Cascio, W., Hong, Y., Howard, G., Lipsett, M., Luepker, R., Mittleman, M., Samet, J., Smith, S.C., Jr., Tager, I. (2004) Air Pollution and Cardiovascular Disease: A Statement for Healthcare Professionals from the Expert Panel on Population and Prevention Science of the American Heart Association. Circulation 109, 2655-2671.

Brunekreef, B., Forsberg, B. (2005) Epidemiological Evidence of Effects of Coarse Airborne Particles on Health. European Respiratory Journal 26, 309-318.

Buonocore, J.J., Lee, H.J., Levy, J.I. (2009) The Influence of Traffic on Air Quality in an Urban Neighborhood: A Community-University Partnership. American Journal of Public Health 99, S629-635.

Burtscher, H. (1992) Measurement and Characteristics of Combustion Aerosols with Special Consideration of Photoelectric Charging and Charging by Flame Ions. Journal of Aerosol Science 23, 549-595.

Cass, G.R., Hughes, L.A., Bhave, P., Kleeman, M.J., Allen, J.O., Salmon, L.G. (2000) The Chemical Composition of Atmospheric Ultrafine Particles. Philosophical Transactions of the Royal Society of London. Series A: Mathematical, Physical and Engineering Sciences 358, 2581-2592.

Chetwittayachan, T., Shimazaki, D., Yamamoto, K. (2002) A Comparison of Temporal Variation of Particle-Bound Polycyclic Aromatic Hydrocarbons (Ppahs) Concentration in Different Urban Environments: Tokyo, Japan, and Bangkok, Thailand. Atmospheric Environment 36, 2027-2037.

Cowen, K., Kelly, T., Coutant, B., Riggs, K. (2001) Ecochem Analytics Pas 2000 Particulate Pah Monitor. Environmental Technology Verification Report.

de Haar, C., Hassing, I., Bol, M., Bleumink, R., Pieters, R. (2006) Ultrafine but Not Fine Particulate Matter Causes Airway Inflammation and Allergic Airway Sensitization to Co-Administered Antigen in Mice. Clinical and Experimental Allergy 36, 1469-1479.

Diaz-Sanchez, D., Garcia, M.P., Wang, M., Jyrala, M., Saxon, A. (1999) Nasal Challenge with Diesel Exhaust Particles Can Induce Sensitization to a Neoallergen in the Human Mucosa. Journal of Allergy and Clinical Immunology 104, 1183-1188.

Diaz-Sanchez, D., Penichet-Garcia, M., Saxon, A. (2000) Diesel Exhaust Particles Directly Induce Activated Mast Cells to Degranulate and Increase Histamine Levels and Symptom Severity. Journal of Allergy and Clinical Immunology 106, 1140-1146.

Dockery, D.W. (2001) Epidemiologic Evidence of Cardiovascular Effects of Particulate Air Pollution. Environmental Health Perspectives 109 Suppl 4, 483-486.

Donaldson, K., Brown, D., Clouter, A., Duffin, R., MacNee, W., Renwick, L., Tran, L., Stone, V. (2002) The Pulmonary Toxicology of Ultrafine Particles. Journal of Aerosol Medicine 15, 213-220.

Fine, P.M., Chakrabarti, B., Krudysz, M., Schauer, J.J., Sioutas, C. (2004) Diurnal Variations of Individual Organic Compound Constituents of Ultrafine and Accumulation Mode Particulate Matter in the Los Angeles Basin. Environmental Science and Technology 38, 1296-1304.

Fruin, S., Westerdahl, D., Sax, T., Sioutas, C., Fine, P.M. (2008) Measurements and Predictors of on-Road Ultrafine Particle Concentrations and Associated Pollutants in Los Angeles. Atmospheric Environment 42, 207-219.

Gonzalez, Y., Rodriguez, S., Guerra Garcia, J.C., Trujillo, J.L., Garcia, R. (2011) Ultrafine Particles Pollution in Urban Coastal Air Due to Ship Emissions. Atmospheric Environment 45, 4907-4914. 
Junker, M., Kasper, M., Roosli, M., Camenzind, M., Kunzli, N., Monn, C., Theis, G., Braun-Fahrlander, C. (2000), Airborne Particle Number Profiles, Particle Mass Distributions and Particle-Bound Pah Concentrations within the City Environment of Basel: An Assessment as Part of the Briska Project. Atmospheric Environment 34, 3171-3181.

Kaupp, H., McLachlan, M.S. (2000) Distribution of Polychlorinated Dibenzo-P-Dioxins and Dibenzofurans (Pcdd/Fs) and Polycyclic Aromatic Hydrocarbons (Pahs) within the Full Size Range of Atmospheric Particles. Atmospheric Environment 34, 73-83.

KEC (2004), Traffic Counting Data, Korea Highway Corporation. pp. 727-730.

Kim, S., Shen, S., Sioutas, C. (2002) Size Distribution and Diurnal and Seasonal Trends of Ultrafine Particles in Source and Receptor Sites of the Los Angeles Basin. Journal of the Air and Waste Management Association 52, 297-307.

Kittelson, D.B. (1998) Engines and Nanoparticles: A Review Journal of Aerosol Science 29, 575-588.

Kwasny, F., Madl, P., Hofmann, W. (2010) Correlation of Air Quality Data to Ultrafine Particles (Ufp) Concentration and Size Distribution in Ambient Air. Atmosphere 1, 3-14.

Levy, J.I., Houseman, E.A., Spengler, J.D., Loh, P., Ryan, L. (2001) Fine Particulate Matter and Polycyclic Aromatic Hydrocarbon Concentration Patterns in Roxbury, Massachusetts: A Community-Based Gis Analysis. Environmental Health Perspectives 109, 341-347.

Li, N., Sioutas, C., Cho, A., Schmitz, D., Misra, C., Sempf, J., Wang, M., Oberley, T., Froines, J., Nel, A. (2003) Ultrafine Particulate Pollutants Induce Oxidative Stress and Mitochondrial Damage. Environmental Health Perspectives 111, 455-460.

Li, N., Wang, M., Bramble, L.A., Schmitz, D.A., Schauer, J.J., Sioutas, C., Harkema, J.R., Nel, A.E. (2009) The Adjuvant Effect of Ambient Particulate Matter Is Closely Reflected by the Particulate Oxidant Potential. Environmental Health Perspectives 117, 1116-1123.

Li, N., Xia, T., Nel, A.E. (2008) The Role of Oxidative Stress in Ambient Particulate Matter-Induced Lung Diseases and Its Implications in the Toxicity of Engineered Nanoparticles. Free Radical Biology and Medicine 44, 1689-1699.

Nel, A., Xia, T., Madler, L., Li, N. (2006) Toxic Potential of Materials at the Nanolevel. Science 311, 622-627.

Nel, A.E., Diaz-Sanchez, D., Ng, D., Hiura, T., Saxon, A. (1998) Enhancement of Allergic Inflammation by the Interaction between Diesel Exhaust Particles and the Immune System. Journal of Allergy and Clinical Immunology 102, 539-554.

Noble, C.A., Mukerjee, S., Gonzales, M., Rodes, C.E., Lawless, P.A., Natarajan, S., Myers, E.A., Norris, G.A., Smith, L., Ozkaynak, H., Neas, L.M. (2003) Continuous Measurement of Fine and Ultrafine Particulate Matter, Criteria Pollutants and Meteorological Conditions in Urban El Paso, Texas. Atmospheric Environment 37,
827-840.

Oberdorster, G. (1996) Significance of Particle Parameters in the Evaluation of Exposure-Dose-Response Relationships of Inhaled Particles. Inhalation Toxicology 8 Suppl, 73-89.

Oberdorster, G., Oberdorster, E., Oberdorster, J. (2005) Nanotoxicology: An Emerging Discipline Evolving from Studies of Ultrafine Particles. Environmental Health Perspectives 113, 823-839.

Park, K., Park, J.Y., Kwak, J.H., Cho, G.N., Kim, J.S. (2008) Seasonal and Diurnal Variations of Ultrafine Particle Concentration in Urban Gwangju, Korea: Observation of Ultrafine Particle Events. Atmospheric Environment 42, 788-799.

Pekkanen, J., Peters, A., Hoek, G., Tiittanen, P., Brunekreef, B., de Hartog, J., Heinrich, J., Ibald-Mulli, A., Kreyling, W.G., Lanki, T., Timonen, K.L., Vanninen, E. (2002) Particulate Air Pollution and Risk of St-Segment Depression During Repeated Submaximal Exercise Tests among Subjects with Coronary Heart Disease: The Exposure and Risk Assessment for Fine and Ultrafine Particles in Ambient Air (Ultra) Study. Circulation 106, 933-938.

Pope, C.A., 3rd, Burnett, R.T., Thun, M.J., Calle, E.E., Krewski, D., Ito, K., Thurston, G.D. (2002) Lung Cancer, Cardiopulmonary Mortality, and Long-Term Exposure to Fine Particulate Air Pollution. JAMA 287, 11321141.

Pope, C.A., 3rd, Dockery, D.W. (2006) Health Effects of Fine Particulate Air Pollution: Lines That Connect. Journal of the Air and Waste Management Association $56,709-742$.

Ramamurthi, M., Chuang, J.C. (1997) Field and Laboratory Evaluations of a Real-Time Pah Analyzer, USEPA.

Salvi, S., Blomberg, A., Rudell, B., Kelly, F., Sandstrom, T., Holgate, S.T., Frew, A. (1999) Acute Inflammatory Responses in the Airways and Peripheral Blood after Short-Term Exposure to Diesel Exhaust in Healthy Human Volunteers. American Journal of Respiratory and Critical Care Medicine 159, 702-709.

Salvi, S.S., Nordenhall, C., Blomberg, A., Rudell, B., Pourazar, J., Kelly, F.J., Wilson, S., Sandstrom, T., Holgate, S.T., Frew, A.J. (2000) Acute Exposure to Diesel Exhaust Increases Il-8 and Gro-Alpha Production in Healthy Human Airways. American Journal of Respiratory and Critical Care Medicine 161, 550-557.

Sapkota, A., Buckley, T.J. (2003) The Mobile Source Effect on Curbside 1,3-Butadiene, Benzene, and Particle-Bound Polycyclic Aromatic Hydrocarbons Assessed at a Tollbooth. Journal of the Air \& Waste Management Association 53, 740-748.

Sioutas, C., Delfino, R.J., Singh, M. (2005) Exposure Assessment for Atmospheric Ultrafine Particles (Ufps) and Implications in Epidemiologic Research. Environmental Health Perspectives 113, 947-955.

Timonen, K.L., Hoek, G., Heinrich, J., Bernard, A., Brunekreef, B., de Hartog, J., Hameri, K., Ibald-Mulli, A., Mirme, A., Peters, A., Tiittanen, P., Kreyling, W.G., 
Pekkanen, J. (2004) Daily Variation in Fine and Ultrafine Particulate Air Pollution and Urinary Concentrations of Lung Clara Cell Protein Cc16. Occupational and Environmental Medicine 61, 908-914.

Wehner, B., Birmili, W., Gnauk, T., Wiedensohler, A. (2002) Particle Number Size Distributions in a Street Canyon and Their Transformation into the Urban-Air Background: Measurements and a Simple Model Study. Atmospheric Environment 36, 2215-2223.

Zhang, Q., Stanier, C.O., Canagaratna, M.R., Jayne, J.T., Worsnop, D.R., Pandis, S.N., Jimenez, J.L. (2004)
Insights into the Chemistry of New Particle Formation and Growth Events in Pittsburgh Based on Aerosol Mass Spectrometry. Environmental Science and Technology 38, 4797-4809.

Zhu, Y., Hinds, W.C., Kim, S., Sioutas, C. (2002) Concentration and Size Distribution of Ultrafine Particles near a Major Highway. Journal of the Air and Waste Management Association 52, 1032-1042.

(Received 7 December 2011, revised 1 April 2012, accepted 1 April 2012) 